\title{
Implementasi Total Quality Manajement (TQM) di Lembaga Pendidikan
}

\author{
Oleh : khoirul Anam \\ NIM : 1630500084 \\ Email : anamkhoiru10697@gmail.com
}

\begin{abstract}
Abstrak
Kualitas adalah suatu tujuan dan sekaligus harapan bagi semua pihak bagi yangmendambakankemajuan dan keberhasilan. TQM merupakan salah satu bentuk upayapencapaian kualitas. Dengan penerapan TQM pada sebuah perguruan tinggi diharapkankiranya dapat membangun sebuah system perguruan tinggi yang mampu menampilkansikap open manajemen dalam berbagai diminesi. Sehingga kepuasan yang menjadi ukurandan harapan semua stakeholder yang ada dapat terwujud dengan sebaik-baiknya.Kehadiran TQM pada perguruan tinggi berdampak pada perubahan manajemenkonvensional.
\end{abstract}

\section{Kata Kunci : implementasi TQM dan perbaikan terus menerus}

\section{Pendahuluan}

Pada dasarnya, setiap lembaga pendidikan atau sekolah mengingkan memiliki mutu yang tinggi dan unggul. Untuk menjadikan mutu yang unggul, lembaga pendidikan harus menerapkan dan melaksanakan Total Quality Manajement (TQM) atau dalam bahasa Indonesia biasa dikenal dengan istilah Manajemen Mutu Terpadu (MMT). Total Quality Manajementmerupakan suatu usaha keras yang membutuhkan kerja sama dari semua instansi pendidikan, terkait perwujudan mutu pada lembaga pendidikan atau sekolah. Pada awalnya Total Quality Manajement (TQM) berasal dari dunia bisnis dan terapkan husus dalam dunia perusahaan saja, tetapi seiring dengan berjalannya waktu, Total Quality
Manajement (TQM) juga diterapkan pada dunia pendidikan atau sekolah. Berawal dari hal itulah, untuk memahami TQM harus merujuk pada dunia asalny. Hal ini bukan berarti metode bisnis lebih unggul dari pada praktik pendidikan tau pendidikan akan ditingkatkan hanya dengan mengadopsi bahasa komersial. Lebih dari itu, justru dunia pendidikan dapat belajar dari metode yang diterapkan dibeberapa lembaga pendidikan atau sekolah.

Bab ini secara berturut-turut akan membahas TQM di lembaga pendidikan, manajemen sumber daya manusia (MSDM) dalam Total Quality Manajement (TQM), dan penerapan total TQM dalam proses pengajaran di sekolah.

Implementasi Total Quality Manajement| 1 
Iplementasi Total Quality Manajement di lembaga pendidikan

Bagi suatu lembaga pendidikan atau sekolah, mutu adalah agenda terpenting dan memang seharusnya diupayakan dan diwujudkan. Hal ini dikarenakan sekolah yang bermutu memiki banyak peminat dibandingkan yang tidak bermutu. Usaha untuk meningkatkan mutu merupakan tugas paling penting dan merupakan PR bagi lembaga pendidikan atau sekolah yang belum bermutu. Bagi lembaga pendidikan yang belum bermutu, hendaknya berlomba-lomba mengupayakan mutu sekolah sehingga hal yang menjadi daya tarik dan nilai plus di sekolah tersebut, itulah yang dikembangkan. Bagi lembaga sekolah yang sudah bermutu, tindakan yang perlu dilakukan adalah mempertahankan apa yang telah didapat dengan catatan ada inovaasi yang dilakukan secara terus menerus. Buatlah lembaga pendidikan atau sekolah berbeda dengan lembaga pendidikan lain, karena hal tersebut merupakan daya tarik tersendiri bagi para masyarakat dan orang tua yag ingin menyekolahkan putra-putrinya.

\section{Pengertian Total Quality Manajement}

Total Quality Manajemen t(TQM) ialah suatu pendekatan dalam usaha memaksimalkan daya saing melalui perbaikan terus menerus atas jasa, manusia, produk dan lingkungan. Di dalam Total Quality Manajement (TQM), terdapat serangkaian usaha untuk memaksimalkan semua fungsi organisasi dalam falsafah holistik yang dibangun berdasarkan konsep mutu, kerja tim, efektivitas, dan prestasi beserta kepuasan pelanggan.

Ini menunjukkan bahwa TQM merupakan suatu sistem manajemen yang menyangkut mutu sebagai strategi usaha berorientasi pada kepuasan pelanggan dengan melibatkan seluruh anggota organisasi. Di dalam Total Quality Manajementyang diutamakan pertama, total. Total dalam TQM merupakan strategi organisasional menyeluruh yang melibatkan semua jenjang dan jajaran manajemen dan karyawan, bukan hanya pengguna ahir dan pembeli eksternal saja, melainkan pula pelanggan internal, pemasok, bahkan personalia pendukung. Kedua, kualitas. Kualitas di dalam TQM lebih menekankan pelayanan kualitas, bukan sekedar produk bebas cacat. Kualitas didevinisikan oleh pelanggan, ekspektasi pelanggan bersifat individual, tergantung pada latar belakang sosial ekonomis dan karakteristik demografis. Ketiga, manajemen di dalam TQM merupakan pendekatan manajemen, bukan pendekatan teknis pengendalian kualitas yang sempit.

Berdasarkan beberapa pengertian TQM diatas, paling tidak terdapat empat konsep TQM, antara lain: quality, kepuasan pelanggan, perbaikan terus menerus, dan menyeluruh seluruh komponen.

\section{Impplementasi Total Quality Manajement (TQM) di Lembaga Pendidikan}

Mutu dapat diukur dari kepuasan pelanggan atau penggunaan pendidikan. Beranjak dari hal tersebut maka immplementasi Total Quality Manajement di lembaga 
pendidikan ada bebrapa hal yang harus diperhatikan, pertama, ada perbaikan secara terus-menerus (continuos improvement). Perbaikan senantiasa dilakukan secara terusmenerus ooleh lembaga pendidikan atau sekolah kearah peningkatan yang lebih baik.

Kedua, adanya standar mutu. Setiap lembaga pendidikan atau sekolah pasti mempunyai standar tersendiri untuk mengembangkan mutu lembaganya tetrsebut. Adanya tujuan ini bertujuan sebagai dasar landasan dalam pengembangan mutu. Dengan adanya standar, lembaga pendidikan berusaha keras untuk mengembangkan lembaganya. Ketiga, adanya perubahan budaya dan kultur (change of culture). Pada tahap ini lembaga pendidikan harus pandai dalam menyeleksi budaya atau kultur yang ada pada lembaganya. Budaya yang negatif sebaiknya ditinggalkan, sedangkan budaya yang positif sebaiknya dipertahankan. Keempat, adanya perubahan organisasi. Organisasi yang dianggap kurang efektif hendaknya juga ditinggalkan. Organisai harus diarahkan pada upaya pengembangan dan peningkatan mutu. Perubahan organisasi ini harus bersifat menyeluruh.

Kelima, adanya usaha untuk mempertahankan hubungan baik dengan para pelanggan. Hubungan baik dengan pelanggan pendidikan memang seharusnya dijaga dengan baik. Agar hubungan tersebut tetap tetap terjaga dengan baik, harus ada komunikasi yang terjalin antara pihak lembaga pendidikan atau sekolah dengan pelanggan pendidikan.
Selain usaha perbaikan-perbaikan yang dilakukan di atas, ada satu masalah yang menjadi masalah utama dan penting untuk ditangani dalam dunia pendidikan adalah masih rendahnya mutu keluaranya (output). Indikator yang menjadi acuhan untuk menguatkan pernyataan tersebut adalah Nilai Ujian Nasional (NUN) yang secara umum belum terlalu mengembirakan. Upaya menigkatkan mutu pendidikan telah lama diangkat oleh pemerintah sebagai salah satu kebijaksanan strategis yang terdiri atas perluasan kesempatan belajar, meningkatkan mutu pendidikan, peningkatan relevansi, serta efisiensi dan efektifitas penyelenggara pendidikan. Kemudian, mengadakan serangkain kegiatan penataan guru, pembentukan Musyawarah Guru Pelajaran Sejenis (MGMP), didirikannya Pusat Kegiatan Guru (PKG), Lembaga Balai Penataan Guru (BPG), dan lain sebagainya. Namun, tidak sertamerta persoalan tersebut bisa terselesaiikan.

Prosedur dalam mengemplementasikan TQM pada dasarnya menempuh tiga tahapan sebagai berikut.

a. Persiapan

Tahapan persiapan adalah aktivitas pertama dan utama yang harus dilakukan sebelum TQM dikembangkan dan dilaksanakan. Beberapa langkah yang harus dilakukan adalah membentuk tm dan melaksanakan pelatihan TQM bagi tim. Merumuskan model atau sistem yang akan dikembangkan sebagai nama implementasi TQM, membuat kebijakan berkaitan dengan kometmen anggota organisasi untuk mendukung TQM, mengomonikasikan 
kepada seluruh anggota organisasi berkaitan dengan adanya perubahan, melakukan anlisis faktor pendukung dan penghambat organisasi, dan melakuakan pengukuran terhadap kepuasan pelanggan.

b. Pengembangan sistem

Berdasarkan tahapan persiapan, pengembangan sistem dapat dilakukan dengan langkah-langkah sebagai berikut: peninjauan dan pengembangan model atau sistem yang ada melalui penyusunan dokumen sistem kualitas, melakukan pelatihan, dan sosialisasi prosedur dan petunjuk kerja pada tim-tim yang ditentukan secara tuntas, serta melakukan penyiapan ahir, baik sumber daya manusia maupun non manusia secara cermat dan akurat dalam memasuki memasuki tahapan implementasi sistem kualitas.

c. Implememtasi sistem

Tahapan implementasi sistem menunjuk pada langkah-langkah sebagai berikut:melakukan uji coba sistem jaminan kualitas dalam lingkup tertentu beerdasarkan siklus PDCA (plan,do,check, act), anggota tim mengimpormasikan kepada pemimpin maupun steering commite berkaitan dengan uji coba sistem jaminan kualitas yang telah dilaksanakan secara rinci, tim mengumpulkan data dan imformasi dari pelanggan, melakukan tindakan koreksi dan pencegahan sesuai dengan harapan pelanggan, dan mendiskusikan/ melaksanakan rapat pemimpin dan pelaksana sistem jaminan kualitas berkaitan denga seluruh balikan yang ada untuk menghasilkan atau membuat modifiksi proses yang diharapkan secara terusmenerus dan berkesinambungan. ${ }^{1}$

Menilai mutu dalam bidang jasa sangatlah tidak mudah sebab yang dinilai dari segi kuanitatif. Segi kuanitatif seperti gedung sekolah atau labotorium yang berhasil dibangun, sementara lagi kualitatif, misalnya biasanya mamfaat dan kemampuan memamfaatkannya. Menurut Hadari Nawawi, ukuran produktivitas organisasi bidang pendidikan dapat dibedakan sebagai berikut.

a. Produktivitas internal, berupa hasil yang dapat diukur secara kuantitati, seperti jumlah atau persentase lulusan sekolah, atau jumlah gedunng dan lokal yang dibangun sesuai dengan persyaratan yang telah di tetapkan

b. Produktivitas internal, berupa hasil yang tidak dapat diukur secara kuantitatif, karena bersifat kualitatif yang hanya dapat diketahui setelah melewati tenggang waktu tertentu yang cukup lama.

Keberhasilan aplikasi Manajemen mutu Terpadu (MMT) di sekolah diukur dari:pertama, tingkat kepuasan pelanggan, baik internal maupun eksternal. Dengan kata lain, kebrhasilan sekolah dikemukakan dalam panduan manajemen sekolah apabila siswa merasa puas dengan layanansekolah. Orang tua siswa merasa puas dengan layanan terhadap anaknya. Ketiga, pemakai atau penerima lulusan merasa puas karena menerima lulusan dengan

\footnotetext{
${ }^{1}$ Hadari Nawawi, Manajemen stategik. (Yokyakarta: Gadjah Mada Pres, 2005), hlm 47.
}

Implementasi Total Quality Manajement | 4 
kualitas tinggi dan sesuai harapan. Keempat, guru dan karyawan merasa puas dengan pelayanan sekolah.

Sekolah bisa menghasikan lulusan yang bermutu apbila penyelenggaraan mutunya terjamin. Mutu pendidikan akan terjamin ketika kepala sekolah melaksanakan fungsi kepemimpinannya dengan baik dan barengi komponen pendidikan yang berkualitas, atau dalam bahasa yang lain terjadi adanya sinergitas yang berorientasi pada mutu pendidikan antara pemimpin dan seluruh civitas akademika di

\begin{tabular}{|c|c|c|c|}
\hline No & KeadaanImput & $\begin{array}{c}\text { Keadaan } \\
\text { Proses }\end{array}$ & Keadaan Output \\
\hline 1 & Baik & Baik & PastiBaik \\
\hline 2 & Baik & Sedang & Sedang \\
\hline 3 & Baik & Jelek & Meningkat \\
\hline 4 & Sedang & Baik & Tetap \\
\hline 5 & Sedang & Sedang & Makin Jelek \\
\hline 6 & Sedang & Jelek & Sedang \\
\hline 7 & Rendah & Baik & CenderungSedikitMeningkat \\
\hline 8 & Rendah & Sedang & \\
\hline 9 & Rendah & Jelek & PastiRendah \\
\hline
\end{tabular}
lembaga pendidikan tersebut.

Pendidikan yang bermutu ditentuan oleh beberapa komponen yang terkait, mulai dari imput (masukan), proses, dan output (keluaran) serta dengan pengelolaan manajemen yang bagus. Rachman menyatakan bahwa manajemen peningkatan mutu pendidikan memiliki karaktristik yang perlu dipahami oleh lembaga pendidikan yang akan menerapkannya, yaitu karakteristik sekolah yang efektif (effektive school) dan manajemen peningkatan mutu pendidikan yang merupakan wadah dan kerangkanya. Lazimnya memang formula imput, proses, dan output, ini selalu dipakai. Untuk lebih jelasnya, perhatikan tabel korelasi antara imput, proses dan output dalam pendidikan berikut.

Tabel 1

KorelasiantaraImput, Proses, dan Output

Tabel tersebut menunjukk bahwa keadaan proses lebih berpengaruh daripada imput. Namun umumnya, lembaga yang ada selalu mengandalkan kualitas imput-nya, termasuk lembaga pendidikan yanngg sudah maju, yang biasa disebut lembaga yang bonafit, model, plus, atau unggulan, sesmua mengandalkan pada sisi imput. Implikasinya, lembega pendidikan tersebut dengan seenaknya hanya menerima siswa yang pandai-pandai.

Mestinya, ketika ada lembaga pendidikan yang mengklaim diri sebagai lembaga pendidikan yang maju, bonatif, model, plus maupun unggulanl, ia harus membuktikan kepada publik mampu menjadikan anak yang asalnya lambat mampu menjadikan anak yang pandai melalui berbagai upaya terobosan strategis. Namun sayangnya, belum ada lembaga yang berani mempraktekan gagasan tersebut.

Oleh karena itu, manajer lembaga pendidikan harus berkonsentrasi pada upaya menajadikan imput yang baik melalui proses yang sangat baik untuk menghasilkan output

Implementasi Total Quality Manajement| 5 
yang unggul/istimewa; imput sedang melaui proses yang istimewa menghasilkan output yang baik sekali; imput yang baik. Lebih jelasnya dapat diperhatikan melaui tabel berikut ini.

Tabel 2

Proses PengelolaanImputPendidilkan

\begin{tabular}{|c|c|c|c|}
\hline No & KeadaanImput & Keadaan Proses & Keadaan Output \\
\hline 1 & Baik & SangatBaik & Unggul Istimewa \\
\hline 2 & Sedang & Istimewa & BaikSekali \\
\hline 3 & Rendah & Sangat Istimewa & Baik \\
\hline
\end{tabular}

Dari tabel di atas, dapat dikatakan apabila kepala sekolah mampu mewujudkan perubahan pada siswa dari baik menjadi istimewa, dari sedang menjadi baik sekali, dan dari rendah menjadi baik, ia mampu menghadikan pendidikan yang sejati. Kepala sekolah/ pemimpinan merupakan pahlawan pendidikan. Sebab, jati diri pendidikan sesungguhkanya terletak pada kemampuannya mengubah siswa menjadi lebih baik lagi.

Model pendidikan demikian inilah yang seharusnya terjadi dan dan dapat disebut sebagai pendidikan emansipatoris. Pendidikan emansipatoris, yaitu suatu pendidikan yang berperan membebaskan siswa dari kebodohan, keterbelakangan, keterbelengguan, ketersesatan, dari kemaksiatan. ${ }^{2}$ jadi, pendidikan benar-benar hadir sebagai lembaga yang mampu menolong dampu memberi jalan keluhuran bagi siswa sehingga benar-benar terjadi perubahan positikonstruktif.

${ }^{2}$ Zainal Arifin, epaluasi pembelajara: prinsip, teknik, prosedur. (Bandung: Remaja Rosdakarya, 2011), hlm.55.
Perwujudan perubahan seperti ini sungguh tidak mudah. Akan tetapi, harus dilakukan oleh pimpinan lembaga pendidikan terutama guru/dosen karena siswa berasal dari kalangan kelas menengah kebawah secara intelektual. Kondisi semacam ini memang membutuhkan model pendidikan yang menerapkan strategi ganda. Oleh karena itu, pelaksanaan pendidikan harus mengandalkan proses dengan rekayasa menuju metode, penddekatan, maupun strategi yang mampu mempercepat pemberdayaan siswa secara maksimal.

\section{Hambatan implementasi Total Quality Manajement (TQM) di Lembaga Pendidikan}

Setidaknya terdapat dua factor yang dapat menjelaskan mengapa upaya perbaikan mutu pendidikan selama ini kurang atau tidak berhasil. Pertama, pembangunan lebih bersifat imput oriented, semua imput pendidikan telah dipenuhi, seperti menyediakan buku-buku (media ajar) dan alat belajar lainnya, penyediaan sarana pendidikan, pelatihan guru dan tenaga kependidikan lainnya maka secara otomatis lembaga pendidikan (pendidikan dasar, pendidikan menengah, dan pendidikan tinggi) akan menghasilkan output (keluaran) bermutu sebagaimana diharapkan.

Kedua, pengelolaan pendidikan selama ini masih bersifat macro oriented, diatur oleh jajaran birokrasi di tingkat pusat. Akibatnya factor yang diproyeksikan di tingkatmakro (pusat) tidak terjadi atau tidak berjalan sebagaimana mestinya di tingkat mikro (lembaga pendidikan). Dengan kata lain, 
kompleksi cakupan permasalahan pendidikan, sering kali tidak dapat terpikirkan secara utuh dan akurat oleh birokrasi pusat. ${ }^{3}$

Abdur Rahman Shaleh menyatakan ada tiga factor yang menyebabkan mutu pendidikan menurun dan mengalami perkembangan yang tidak merata. Pertama, kebijakan penyelenggaraan pendidikan nasional yang menggunakan pendekatan educational production function atau imput-output yang dilaksanakan secara tidak konsekuen. Kedua, penyelenggaraan pendidikan nasional dilakukan secara birokratis-sentralistik sehingga menempatkan sekolah sebagai penyelenggara pendidikan sangat bergantung kepada keputusan birokrasi yang panjang dan kadang-kadang kebijakan yang dikeluarkan tidak sesuai kondisi sekolah setempat. Ketiga, peran serta masyarakat hususnya orangtua siswa dalam penyelenggaraan pendidikan selama ini pada umumnya lebih bersifat imput (dana), bukan pada proses pendidikan (pengambilan keputusan, memonitoring, evaluasi, dan akuntabilitas). ${ }^{4}$

\section{Pendidikan yang bermutu adalah} pendidikan yang mampumenghasilkan lulusan (output) yang memiliki kemampuan atau kompetensi, baik kompetensi akademik maupun kejuruan, yang dilandasi oleh kompetensi personal dan social, baik quality infact maupun

\footnotetext{
${ }^{3}$ ZahrohAminatul, Total Quality Manajement: Teori dan aplikasi manajemen untuk mendongkrak Mutu pendidikan, (Yokyakarta: Ar-Ruzz Media, 2014), hlm. 100

${ }^{4}$ Abdul Rahman Shaleh, madrasah dan pendidikan anak bangsa. (Jakarta: PT. Raja GrafinndoPersada, 2004), hlm. 243-244.
}

quality perception. ${ }^{5}$ Untuk dapat meningkatkan mutu, pendidikan harus dapat melaksanakan pengelolaan yang didasarkan pada peningkatan mutu pendidkan.

$$
\text { Ketika lembaga pendidikan }
$$

mendapatkan penanganan manajerial yang baik sesuai dengan visi dan misinya, peningkatan mutu sekolah akan tercapai. Inilah yang menjadi tujuan dari peningkatan mutu sekolah. Secara terperinci, tuujuan dari program manajemen peningkatan mutu, antara lain sebaagai berikut.

a. Mengembangkan kemampuan kepemimpinan lembaga pendidikan bersama guru, unsur komite sekolah/majlis madrasah dalam aspek manajemen berbasis sekolah untuk meningkatkan mutu sekolah.

b. Mengembangkan kemampuan lembaga pendidikan bersama guru, unsur komite sekolah dalam melaksanakan pembelajaran yang aktif dan menyenangkan, baik di lingkungan sekolah maupun masyarakat setempat.

c. Mengembangkan peran serta masyarakat yang lebih aktif dalam masalah umum persekolahan dari unsur komite sekolah dalam membantu peningkatan mutu sekolah.

Pimpinan lembaga pendidikan harus mulai membaca kecenderungan masyarakat ke depan, kemudian merancang strategi baru terkait dengan penjaminan mutu pendidikan. Masyarakat di masa mendatang sangat mungkin sebelum memasukan anak-anak ke sebuah lembaga pendidikan meminta ketegasan mutu

${ }^{5}$ HariSuderajat, manajemen peningkatan mutu berbasis sekolah. (Bandung: CV. Ciptq Cekas Grafika, 2005), hlm. 17.

Implementasi Total Quality Manajement| 7 
yang dijanjikan. Misalnya, kualitas pendidikan sepearti yang diperoleh anak saya ketika masuk lembaga pendidikan ini? Apa jamiinan anak saya kelak lebih berkualitas melalui proses pembelajaran yang ada di lembaga ini? Apabila mereka dapat diyakinkan melalui jawaban dan bukti riil dari pimpinan, banyak masyakat yang mau memasukkan anaknya lembaga tersebut. Namun, jika masyakat tidak yakin, masyakat batal memasukan anaknya ke lembaga pendidikan lain yang menjanjikan masa depan yang lebih berkualitas. Kecenderungan harus dapat dibaca dan direspon karena masyarakat ke depan terutama dari kalangan terpelajar dan memiliki kecukupan materi, tidak lagi mempermasahkan biaya pendidikan, tetapi cenderung mempermasalahkan mutu.

Sudarwan Danim menyatakan bahwa ketika sekolah-sekolah membuka tawaran dan mampu menggaransi mutu, baik sekolah negri maupun swasta, pilihan masyarakat akan semakin banyak. Kesadaran mereka membayar biayapendidikan tidak lagi ditentukan seberapa besaryang harus disetor ke kas lembaga pendidikan (sekolah), tetapi seberapa baik mutu produk dan jasa yang dibeli untuk dibandingkan dengan lembaga pendidikan lain (sekolah). ${ }^{6}$

Adapun strategi pengelolaan program dapat ditempuh antara lain dengan langkahlangkah sebagai berikut.

a. Memberdayakan komite lembaga
pendidikan dalam peningkatan mutu
pembelajaran.

${ }^{6}$ Sudarwan Danim, Agenda Pembaharuan Sistem Pendidikan. (Yokyakarta: Pustaka Pelajar, 2003), hlm.47. b. Unsur Pemerintah Kabupaten/ Kota dalam hal ini intansi yang terkait antara lain Dinaspendidikan, Badan Perencanaan Kabupaten/Kota, Kementrian Pendidikan Nasional (yang menangani pendidikan SD, SMP, SMA) dan Kementrian Agama (yang menangani pendidikan MI, MTS, dan MA), Dewan Pendidikan Kabupaten/Kota terutama membantu dalam mengoordinasikan dan membuat jaringan kerja (akses) kedalam siklus kegiatan pemerintahan dan pembangunan pada umumnya.

c. Memberdayakan tenaga kependidikan, baik tenaga pengajar (guru), kepala sekolah, petugas bingbingan dan penyuluhan (BP) maupun staf kantor, pejabat-pejabat di tingkat kecamatan, unsur komite sekolah tentang Manajemen Berbasis Sekolah (MBS), pembelajaran yang bermutu dan peran-peran masyarakat.

d. Mengadakan pelatihan dan pendampingan yang sistematis dan konsisten terhaadap pelaksanaan kegiaatan pembelajaran di sekolah agar diketahui berbagai masalah dan kendala yang dihadapi, serta segera dapat diberikan solusi/pemecahan masalah yang diperlukan.

e. Mengelola kegiatan yang bersifat bantuan langsung bagi ssetiap lembaga pendidikan untuk peningkatan mutu pembelajaran, rehabilitasi atau pembangunan sarana dan prasarana pendidikan, dengan membentuk tim yang bersifat husus untuk melayani sekaligus melakukan dukungan dan pengawasan terhadap tim bentukan sebagai pelaksanaan kegiatan tersebut.

Implementasi Total Quality Manajement| 8 
Sekolah/madrasah dipandang sebagai suatu organisasi yang didesain untuk dapat berkonstribusi terhadap peningkatan kualitas hidup bagi masyarakat. Sebagai salah satu upaya peningkatan kualitas sumber daya manusia serta peningkatan derajat sosial masyarakat bangsa, sekolah sebagai institusi pendidikan perlu dikelola, diatur, ditata dan diberdayakan agar sekolah/madrasah dapat menghasilkan produk atau hasil yang maksimal. Dengan kata lain, sekolah/madrasah sebagai tempat penyelenggaraan pendidikan merupakan sistem yang memiliki berbagai perangkatdan unsur yang saling berkaitan serta memerlukan pemberdayaan. ${ }^{7}$

\section{Penutup}

Dari penjelasan di atas dapat disimpulakan bahwa dalam implementasi Total Quality Manajement (TQM) ada beberapa hal yang harus terpenuhi yaitu:

1. ada perbaikan secara terus-menerus (continuos improvement). Perbaikan senantiasa dilakukan secara terus-menerus ooleh lembaga pendidikan atau sekolah kearah peningkatan yang lebih baik.

2. adanya standar mutu. Setiap lembaga pendidikan atau sekolah pasti mempunyai standar tersendiri untuk mengembangkan mutu lembaganya tetrsebut. Adanya tujuan ini bertujuan sebagai dasar landasan dalam pengembangan mutu. Dengan adanya standar, lembaga pendidikan berusaha keras untuk mengembangkan lembaganya.
3. adanya perubahan budaya dan kultur (change of culture). Pada tahap ini lembaga pendidikan harus pandai dalam menyeleksi budaya atau kultur yang ada pada lembaganya. Budaya yang negatif sebaiknya ditinggalkan, sedangkan budaya yang positif sebaiknya dipertahankan.

4. adanya perubahan organisasi. Organisasi yang dianggap kurang efektif hendaknya juga ditinggalkan. Organisai harus diarahkan pada upaya pengembangan dan peningkatan mutu. Perubahan organisasi ini harus bersifat menyeluruh.

5. adanya usaha untuk mempertahankan hubungan baik dengan para pelanggan. Hubungan baik dengan pelanggan pendidikan memang seharusnya dijaga dengan baik. Agar hubungan tersebut tetap tetap terjaga dengan baik, harus ada komunikasi yang terjalin antara pihak lembaga pendidikan atau sekolah dengan pelanggan pendidikan.

\section{Daftar Pustaka}

Zahrohz Aminatul, Total Quality Manajement: Teori dan aplikasi manajemen untuk mendongkrak Mutu pendidikan, (Yokyakarta: Ar-Ruzz Media, 2014).

Hadari Nawawi, Manajemen stategik. (Yokyakarta: Gadjah Mada Pres, 2005).

Zainal Arifin, epaluasi pembelajara: prinsip, teknik, prosedur. (Bandung: Remaja Rosdakarya, 2011).

Abdul Rahman Shaleh, madrasah dan pendidikan anak bangsa. (Jakarta: PT. Raja Grafindo Persada, 2004).

Implementasi Total Quality Manajement| 9 
HariSuderajat, manajemen peningkatan mutu berbasis sekolah. (Bandung: CV. Cipta Cekas Grafika, 2005).

Sudarwan Danim, Agenda Pembaharuan Sistem Pendidikan. (Yokyakarta: Pustaka Pelajar, 2003).

Sudarwan Danim, Agenda Pembaharuan Sistem Pendidikan. (Yokyakarta: Pustaka Pelajar, 2003).

Baharun Hasan, \& Zamroni, Manajemen Mutu Pendidikan Ikhtiar Dalam Meningkatkan Mutu Pendidikan Madrasah Melalui Pendekatan Balanced Scorecard. (Tulungagung: Akademia Pustaka 2017). 